地すべり 第17巻 第 4 号

Journal of the Japan Society of Landslide 17-4(1981)

\title{
新潟県東山背斜の地すべりとテクトトープ+
}

\section{Tectotope of Landslide Area in the Vicinity of Higashiyama Fold Zone}

\author{
寺川俊浩* 和久紀生* 西田彰一** \\ Takahiro Terakawa, Toshio Waku, Shoichi Nushida
}

\begin{abstract}
The purpose of this report is to discuss the origin and mechanism of landslides in the vicinity of Higashiyama fold zone from the tectonomechanical standpoint. Northern part of Higashiyama anticline is represented as the ansymmetrically overturned anticline, because, the west limb has steep dips and the east limb has gentle dips.

Here the landslides occur at the different areas. One is the eastern limb and the syncline area, where the origin of landslides is considered solely due to physical and chemical properties of rocks.

On the other hand, the southern part of Higashiyama anticline is symmetrical, and both limbs have high angles, where landslides occur intermittently along the anticline axis. We concluded that it is based mainly on the structurally disturved anticline.
\end{abstract}

\section{まえがき}

新潟県長岡市の東方に，南北 $30 \mathrm{~km}$ 以上にわたり連続 して追跡される東山背斜は第 1 級の規模の褶曲である。 この背斜地区は新潟県下でも有数な地すべり多発地帯で ある。地すべり現象が，地すべり地を構成する地質条 件，なかんずく原因（素团）として岩質と地質構造とに 規制されるということはしばしば論じられている。

しかし，このような考察のなかで，原因が岩質にある とか, 否そらではなく地質整造に関係するとかいら論理 が一般に行なわれるが，これは，いわば感性的な発想で あり，本質的な必然的な関係を見拔いていないといって も過言ではなからう。筆者らは東山背斜地区の地すべり 群について主にその構造解析から推考し, 特異な地質構 造の環境（テクトトープ Tectotope）に規制されて発生 したものであるといら見解をここに論ずるすのである。 本文を執笵するにあたり，特に構造物理学的钼点から 御教示を賜わった新潟大学・植村 武教授に感謝の意を 表しなければならない。また，本論のなかで獄干言及す るところがある岩石物性の実験結果については，（株） 日さく・新潟支店の近滕昌敏氏の労によるものであるこ とを付記しお札申し上げる次第である。

\section{1. 東山背斜の構成地質と性格}

新潟平野, 長岡市の東方にある標高 $600 \mathrm{~m}$ 前後の起伏

*（株）日さく新潟支店

***新潟大学名兴教授

†地すべり学会籍18回研究発表会において発表
にとんだし地には “東山背斜”と呼ばれる背斜構造がほ ほ稜線に沿って NNE-SSW 万向に発達している。地質 学的には1930年代の頃から東山背斜がどのような過程で 形成されたものであるか，その成因・機構について諭㼁 されてきた。これらのらち，古くは木村一蔵 (1930) や 高橋純一（1938）によって代表される説によれば，外見 からの形態だけに基づいて背斜形成の成因を横圧力によ るものであるとした。最近では梖山次郎（1978）も褶曲 の成因を座屈褶曲に求め，水平圧縮によってできたもの であることを主張している。一方，金原均二（1950）は 䉼潟油田の地質を総括した論文のなかで，油田の褶曲が 横圧力によって短縮したものとは考光られないとしてい る。最近では小玉喜三郎ら（1974）の研究では，スヶー ル・モデル実験の結果をもあわせて，東山背斜の形成は 主として基盤のブロック状差別年降運動に基づくものと 説明している。このようにもともと地層の褶曲の成因に ついては, 曲げ bending か座屈 bucklingによるかとい ら全く対立した 2 つの就明が行なわれている。

さて，このよらな迂透とも思われる叙述をあえて筆者 らがこころみる所以は，実は地すべりの発生は基本的に は, 褶曲の形成にともなら岩石物性の変化（後生的な因 子）が素因のルーツと考えられるからである。

\section{1）東山背斜の構成地質}

東山背斜とその周辺を構成している地凬は, 新第三紀 の寺泊層，椎谷層，西山層，灰爪壓などである。寺泊周 は暗灭色泥岩を主とし, 濑い凝灭質砂岩を㣣み背斜の中 核をつくっている。この部分は東山背斜の極隆部にあた 
守門岳
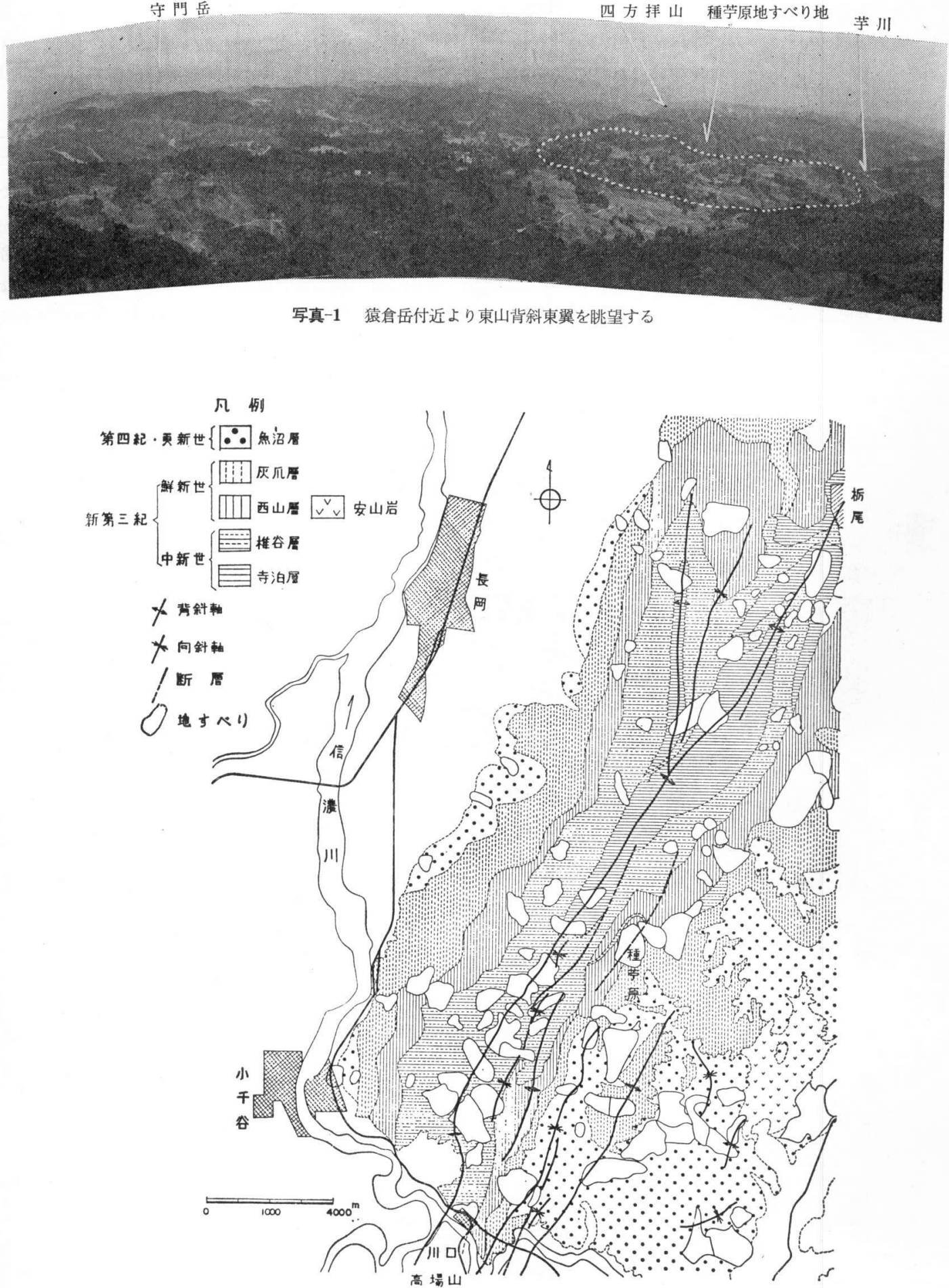

図-1 東山背斜周辺の地質と地すべり分布図

地質構造的には荷頃背斜（東側）之東山背斜（西側） に分岐するところである。この付近には寺泊層の下の七 谷層上部の地層がわずかに露出する。椎谷層は西翼と東
翼とでは岩相の上でかなり様相を異にしている。すなわ ち，本層は西翼では栖吉川上流の露頭に見られるよう に, 石英安山岩凝灰角礫岩・安山岩凝灰角礫岩を主体と 
し，凝灰質砂岩・泥岩互層を介在する。最下部には灰白 色の凝灰質砂岩が発達している。また火山砕屑岩類が占 める厚さも $1,400 \mathrm{~m}$ と最も厚い地区に相当する。

一方, 東翼では寺泊層から凝灰質砂岩・泥岩の互層帯 をへて，その上に同層位の石英安山岩または安山岩質火 山碎履㞸が重なっているが, 中部には一部に泥岩や砂岩 を摤む地層が発達する。西山㬝は灰色泥岩・帯緑灰色泥 岩といったような典型的な grey shale を主体とし，下 部には薄い凝灰觕磁岩・凝灰質砂岩を介在する。また， ところどころに非常にルーズな細磁を混える砂岩を带状 に㣣有するが，この砂岩は細粒磔岩に移化する。

灰爪增は基底に磁石が発達し, 全体として厚い帯緑灰 色砂質泥岩と砂岩との規則正しい互層である。

\section{2）東山背斜の性格}

東山背斜は，NNE-SSW 方向の軸を有し，北端は見 附市の東部から南へ鋸山を経て, 川口町高場山付近で沈 入する長大な背斜である。この背斜は北部では西翼が直 立ないし逆転するといったよらに急傾斜するのに対し， 東翼は緩い傾斜のいわゆる片面箱型の形態を示す。また， 東山背斜の極隆部から分岐し，栃尾へ向って約 $10 \mathrm{~km}$ に わたり荷頃背斜が併走するのが東山背斜の特徴の 1 つで ある。一方, 東山背斜の東方, 破間川の左岸地区は古い 基盤岩類が露出する隆起带となっているが，この隆起帯 と東山背斜に挾まれた地区は，全体としては緩い大きな 向斜構造をつくっている。そのなかには短軸の背斜が 2 列発達する。この地区に地すべりが多発しているのは地

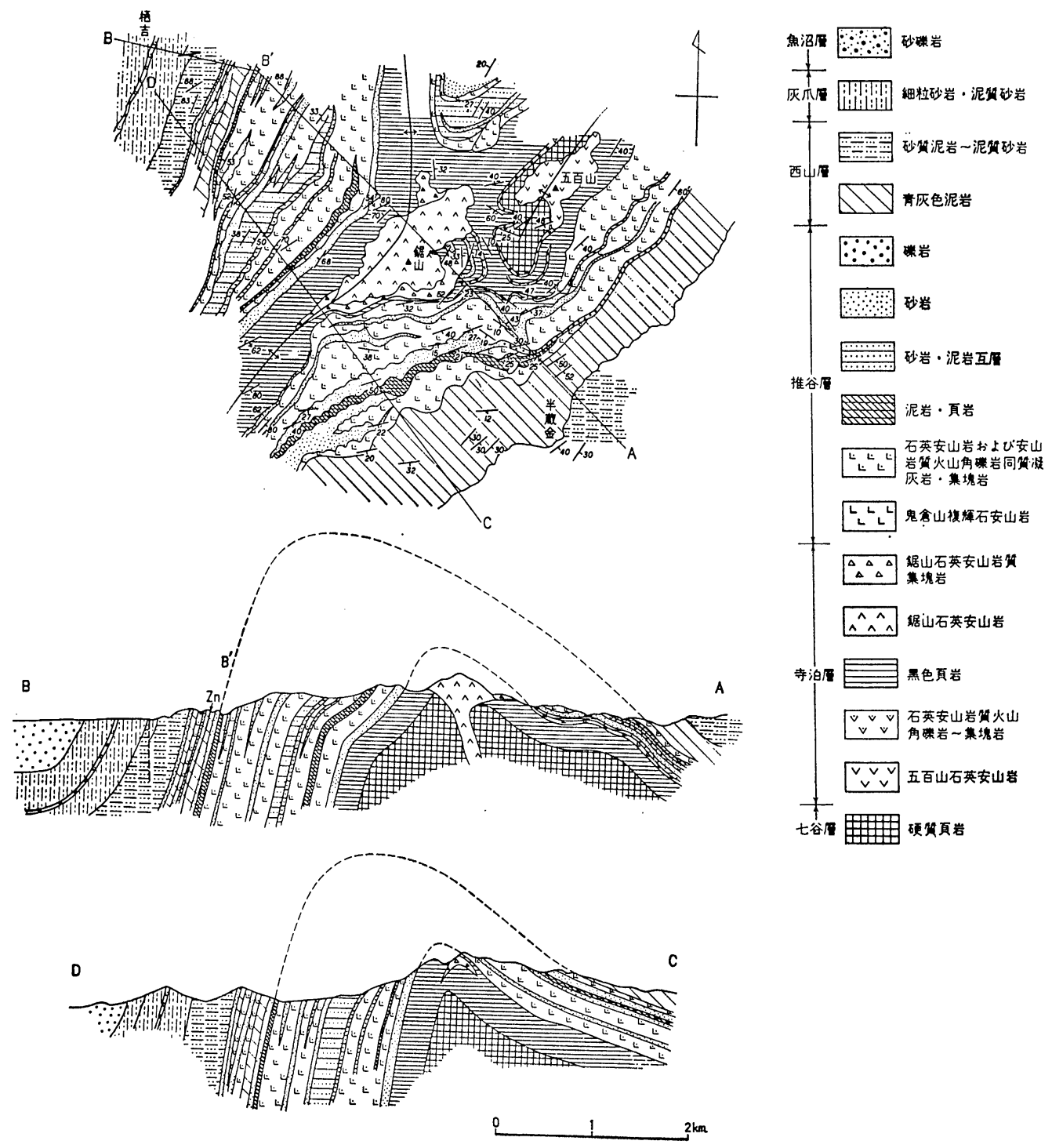

図-2 東山背斜鋸山付近の地質 ·断面図（島田忠夫ほか，1974） 
質構造的に注目すべき現象である。一方, 東山背斜の西側 の平野部には幅の広い低平な大きい向斜が発達する。以 上述べたところは東山背斜周辺の地質構造の概観である。

さて, 褶曲が発達する過程に括いては, 地層の傾動や 伸縮にともなって, 地層のなかに各種の小構造（断裂） が形成されるが，ここで重要なことは，小構造の形成は 䙮曲の発達過程と密接な関係を有しているという点であ る。それは地層が褶曲する過程で，地層を構成する物質 が襢曲内部に拈ける応力とひずみ分布を反映し，それぞ れの位置に変形・破壊構造を刻印するからである。すな わち, 東山背斜に発達する小断層の種類や転位の規模 · 形態なとには，東山背斜の形成機構を直接反映すると考 えられるいくつかの物理的特性がみとめられる。このよ らな意味から東山背斜の性格, つまり力学像・運動像 · ひずみ像をよく理解しておくことが必要である。前述し たように褶曲ができる成因については，今日曲げか座屈

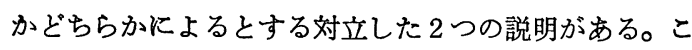
のような東山背斜の成因といら問題は本論の主旨からあ まりにも地質学的な内容に片寄り過ぎるのでこれ以上に 立入って論ずることをひかえることにしたい。曲げと座 屈は力の作用方向が全く異なるから, 地質学的な变形機 構としてはすちろん区別して取扱わねばならないけれど もそれはとるあれ，地すべりという現象に直接関係があ ると思われるのは背斜構造のなかに刻印された変形や断 裂のような小構造といったような具象的な構造要素であ ることを指摘しなければならない。

東山背斜付近の椎谷層や西山層のなかには転位量が数 $\mathrm{cm}$ の小断層から 10 数 $\mathrm{m}$ 以上に拈よぶ規模の大きなるの まで多数の断層が発達する。小玉喜三郎・樋口茂生（19 74)によれば, 表-1のように5つのタイプの断層系統に分 類される。これらの断層のうちA系統のものだけは断層
面が固結した断面であるが，他の断層系はいずれも面が 開離している。また背斜軸に対して縦走性（B，C，E系 統）の断層は比較的直線状に走る場合が多いが，胴切性 のD系統断層は節理が㕍行したタイプを示す。なお $\mathrm{E}$ 系 統の正断層の分布する区域がほぼ東山背斜の頂部付近に 限られているが, 逆にB系統やC 系統の断層はこの部分 には見られずに，急傾斜の背斜翼部に限って観察される。

さて, これら各系統の断層の形成時期には前後関係が 観察されるが, この地域の主要な断裂が, 後期魚沼期以 後のかなり新しい時期に生じた著しい褶曲の成長と時間 的に前後して発達したものと推定され，特に第四紀魚沼 期後の時代に最も大規模に発達したと考察されている。 このことは後に論ずるように，地すべり発生の原因に関 しても閑視することができない問題であるといえる。 さて, 東山背斜は前にも述べたように, 形態的には片 面箱型背斜とみなすことができる（図-2）。すなわちこ の型の背斜の構造は断面図にもらかがわれるよらに西翼 が急, 東翼は傾といったように非対称的背斜を形成す る。しかし，この形態は背斜の北部にみられるすので, 東山背斜の南部になると両翼ともほぼ同じ傾斜を有する 対称的背斜となっている。また，地すべりの分布を概観 しても北部ではむしろ東翼に多く, 南部では背斜軸部に 集中しているという特徵的な傾向がある。すなわち，背 斜北部では位直的に背斜軸からは離れた場所に，むしろ 向斜部に多く発生しているといら現象がみられるのに対 し，虫亀・下寺などの地すべりは軸部に沿って分布して いる点で注目される。昭和55年 4 月 7 日, 虫龟地すべり に隣接したところで発生した地すべりる構造的位置から すると軸部に近い地すべりと見做すことができるととも に，括そらく背斜軸に沿って走る断裂線が素因である可 能性がある。一方, 前にも述べたように東山背斜は極隆

表-1 東山背斜周辺の断層系

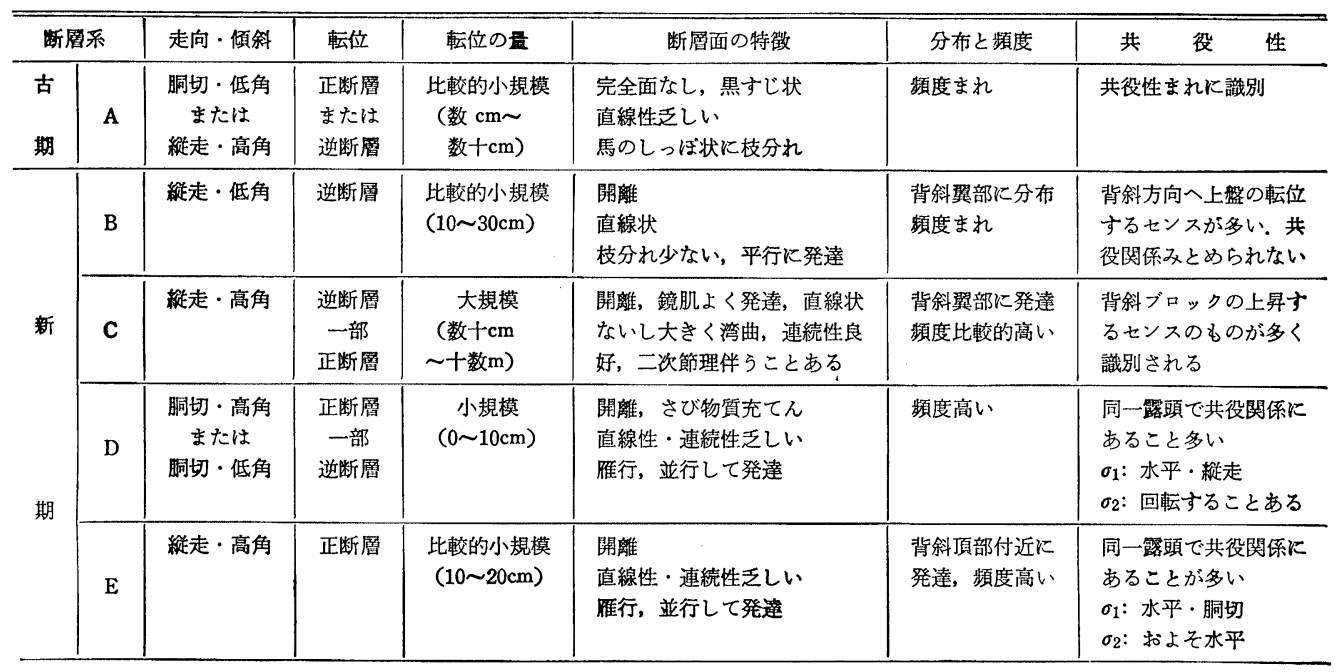


部の鋸山付近から分忮して走る荷頃背斜が発達するが， この背斜は規模は小さいが対称的背斜といえる。そして， 荷頃背斜の地すべりは矢津地すべりによって代表される ように,やはり軸部に沿って発生している。

ところで，新潟平野西辺の丘陵地帯にはほぼ海岸線に 平行に走る中央油帯背斜と呼ばれる背斜が発達している。 この背斜は延長が $30 \mathrm{~km}$ 以上にも及び, 直線的に延びて いるが，両翼が急傾斜し，西側にわずかに逆転するよら な過褶曲をつくっている。地すべりはこの背斜軸に沿い 集中的に発生しているのが特微である。これは東山背斜 の南部に発生した地すべりと背斜軸との関係に類似して いるという点を指摘できる。つまり, 東山背斜南部の地 すべりの多くは構造的条件が主因であって，西田彰一， 岩公 睴（1976）のいう構造性地すべりの範疇に含めら れるべきものと考察する。これに対してこの背斜の北部 付近の地すべりは背斜の性格からすれば, むしろ岩質性 地すべりといえる。すなわち，東山背斜の性格には $2 つ$ のバターンが存在するものと思われる。そしてこれに加 えてさらに注目すべき現象は，東山背斜にしろ，中央油 带背斜にしてもともに近年の水準点変動から推定すると 活䙮曲といえることである。な抹，活䙮曲と地すべりと の関係については後に述べたい。

\section{2. 地すべりの分布と地形 ·地兵環境}

\section{1）地すべりと斜面傾斜との関係}

東山背斜周辺における斜面の傾斜度は 5 万分の 1 地形 図をもとに，地すべり地内の最高標高と最低標高を求め その間の水平距離との関係から傾斜度を求めた。罒-3は 東山背斜地区の斜面の傾度に対応する地すべり箇所数の 頻度分布を求めたもので，背斜の東翼と西翼执よび地区 全体に分けて表現したものである。

まず, この地区全体の傾向をみると斜面傾斜度 $8^{\circ} \sim 10^{\circ}$ に対応する地すべり箇所数が $31 \%$ と最多を占め, $6^{\circ}$ から

$12^{\circ}$ までの斜面傾斜度でいうと地区全体の $67 \%$ の割合を 示している。また $6^{\circ}$ 以下あるいは $12^{\circ}$ 以上になると地す べり简所数はきわめて少なくなる。永田 聡ら（1974） によれば新潟県下の地すべりは斜面傾斜度が $8^{\circ} \sim 15^{\circ}$ の 範团に全地すべり地の $65 \%$ \%゙含まれ，20までを含める と $80 \%$ 以上になるとしているが, 東山背斜地区に限って もこれとおおむれね同じような傾向がみられる。

次に, 地すべり地を背斜の東翼と西翼とに分けて，そ れぞれの斜面傾斜度に対応する地すべり地の頻度分布を 比較してみると雨者の間にはある程度，特徵的な傾向が あることが指摘できる。すなわち東翼では $6^{\circ}$ 末満が 8 地 区, $6^{\circ} \sim 12^{\circ}$ が32地区, $12^{\circ} \sim 22^{\circ}$ が 7 地区に対して, 西翼 では $6^{\circ}$ 未満が 3 地区, $6^{\circ} \sim 12^{\circ}$ が 40 地区, $12^{\circ} \sim 20^{\circ}$ が 14 地 区になる。このような相違はもちろん東緩西急という地 形的要素によるものであろうが，その根底には両者の地 質構造の本質的差異といら東山背斜の珄格の問題が潜ん でいるといらことを洞察しなければならない。また，当 然ながらこれに加えて西翼部を構成する地層の岩質的相 違をあげることができる。たたここに強調して扰きたい のは, 種芋原地すべりによって代表されるように，東翼 部に括ける局処的な造盆状構造がそのまま地形に反映

（規制）され地下構造と地形という2つの因子とがあい まって水理学的環境をつくっていることが地すべり発生 の起因となっているといらことである。

\section{2）地すべりと谷密度との関係}

東山背斜地区と新潟全域の地すべりと谷密度との関係 は表-2および表-3に示したと拈りである。また，図-4は 谷密度区分とそれに対応する地すべり区数およびその面 積の割合を表わしたものである*。

これらで明らかなように谷密度区分に対する面積の割 合をみると，東山背斜地区では谷密度区分20～25の領域 で 33.7\%，16〜20の領域では24.4\%,11〜15領域で18. 6 \%の割合いにある。この結果，これを新潟県全域と比較 すると全域 では谷密度2 1〜25 領域で 24. 7\%,
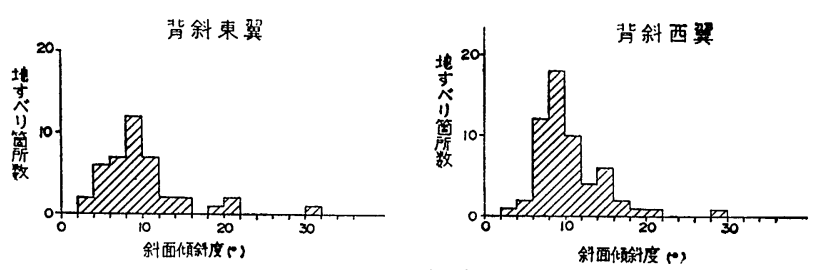

地区全体

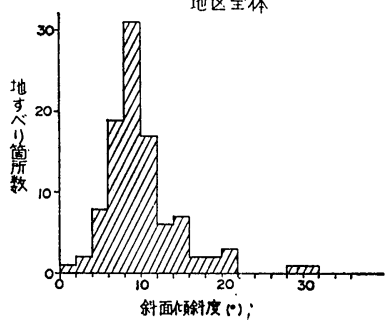

図-3地すへりりと斜面傾斜との関係図
16〜20の領域22.9\%，11～15の領域12.4\%の割 合を示している。このことは東山背斜周辺と新 潟県全域との谷密度区分とそれに対応する面積 の割合の傾向は巨視的には似ているといえる。 つまり, 谷密度区分 $21 \sim 25$ 領域に対応する面積 を最大值として，谷密度が増えても減っても面 積が減ずる頻度分布を示している点では両者は ほぼ同じ傾向にあるといえる。

次に谷密度区分に対する地すべり地区数およ びその占有面積の割合をみると，新潟県全域で は谷密度区分21～25領域に最も地すべり地区数 が多く $37.5 \%$ を占め, その占有面積の割合は $39.7 \%$ にも扣よんでいる。また，谷密度区分 16

*㘡-4の空白の部分は地区数を示す 


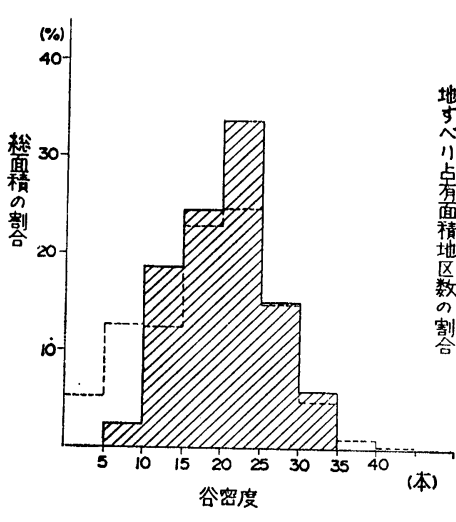

東山背斜地区および新潟全域

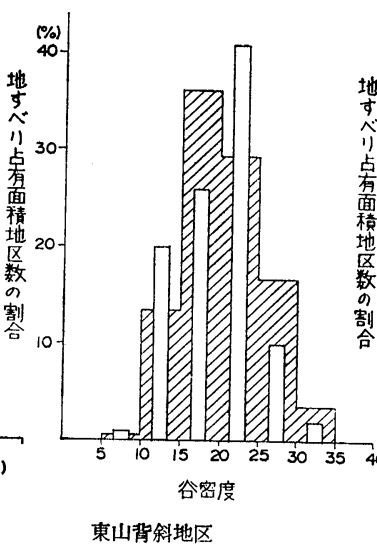

東山背斜地区

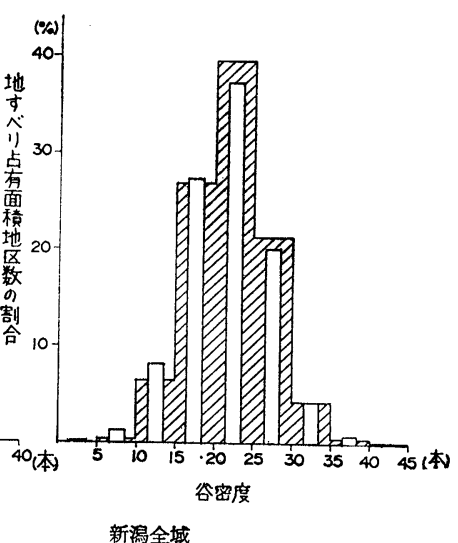

注）白は地区数，斜線は面積を示す

図-4 地すべりと谷密度関係図

表-2 地すべりと谷密度との関係（東山背斜地区）

\begin{tabular}{|c|c|c|c|c|c|c|c|c|}
\hline \multirow{3}{*}{$\begin{array}{l}\text { 谷密度 }^{\text {分 }} \\
\text { (本) }\end{array}$} & \multicolumn{5}{|c|}{ 地すべり地区 } & \multirow{2}{*}{\multicolumn{2}{|c|}{ 全面積 }} & \multirow{3}{*}{ 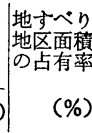 } \\
\hline & \multicolumn{2}{|c|}{ 地区数 } & \multicolumn{2}{|c|}{ 面 樻 } & \multirow{2}{*}{ 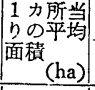 } & & & \\
\hline & 力所 & (\%) & (ha) & (\%) & & (ha) & $(\%)$ & \\
\hline $1 \sim 5$ & 0 & & 0 & & 0 & 0 & & - \\
\hline $6 \sim 10$ & 1 & 1 & 25.0 & 0.6 & 25.0 & 815.9 & 2.4 & 3.1 \\
\hline $11 \sim 15$ & 20 & 20 & 534.5 & 13.4 & 26.7 & 6526.8 & 18.6 & 8.2 \\
\hline $16 \sim 20$ & 26 & 26 & 1439.5 & 36.2 & 55.4 & 8566.4 & 24.4 & 16.8 \\
\hline $21 \sim 25$ & 41 & 41 & 1171.0 & 29.4 & 28.6 & 11829.8 & 33.7 & 9.9 \\
\hline $26 \sim 30$ & 10 & 10 & 667.0 & 16. 8 & 66.7 & 5303.0 & 15.1 & 12.6 \\
\hline $31 \sim 35$ & 2 & 2 & 141.5 & 3.6 & 70.8 & 2039.6 & 5.8 & 6.9 \\
\hline it & 100 & 100 & 3978.5 & 100 & 39.8 & 35081.5 & 100 & 11.3 \\
\hline
\end{tabular}

表-3 地すべりと谷密度との関係（新鼬全域）

\begin{tabular}{|c|c|c|c|c|c|c|c|c|}
\hline \multirow{3}{*}{ 谷密庋 } & \multicolumn{5}{|c|}{ 地すべり地区 } & \multirow{2}{*}{\multicolumn{2}{|c|}{ 全面積 }} & \multirow{3}{*}{ 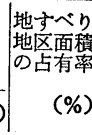 } \\
\hline & \multicolumn{2}{|c|}{ 地区数 } & \multicolumn{2}{|c|}{ 面 積 } & \multirow{2}{*}{ 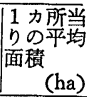 } & & & \\
\hline & 力所 & (\%) & (ha) & (\%) & & (ha) & $(\%)$ & \\
\hline 1本未満 & 0 & & 0 & - & 0 & 17525 & 1.4 & - \\
\hline $1 \sim 5$ & 1 & 0.1 & 18 & 0.0 & 18 & 65626 & 5.2 & - \\
\hline $6 \sim 15$ & 21 & 1.3 & 333 & 0.4 & 15.9 & 158472 & 2.6 & 0.2 \\
\hline $11 \sim 15$ & 132 & 8. 3 & 4903 & 6.5 & 37.1 & 156234 & 12.4 & 3.1 \\
\hline $16 \sim 20$ & 437 & 27.4 & 20481 & 27.0 & 46.9 & 288232 & 22.9 & 7.1 \\
\hline $21 \sim 25$ & 597 & 37.5 & 30146 & 39.7 & 50.5 & 310604 & 24.7 & 9.7 \\
\hline $26 \sim 30$ & 322 & 20.2 & 16288 & 21.5 & 50.6 & 184946 & 4.8 & 8.8 \\
\hline $31 \sim 35$ & 68 & 4.3 & 3271 & 4.3 & 48.1 & 60033 & 4.8 & 5.5 \\
\hline $36 \sim 40$ & 13 & 0.8 & 385 & 0.5 & 29.6 & 13051 & 1.0 & 2.9 \\
\hline $41 \sim 45$ & 2 & 0.1 & 50 & 0.1 & 25.0 & 2983 & 0.2 & 1.7 \\
\hline 即 & 1593 & 100 & 75875 & 100 & 47.6 & 1257706 & 100 & 6.0 \\
\hline
\end{tabular}

～30領域では地区数で85\%，占有面積で88\%の地すべり 地が分布する。

一方，東山背斜地区では新潟県全域と同じうに谷密 度区分21 25領域で最も多く, 地すべり占有面積では 16 ～20領域では $36.2 \%$ と最大面積を示している。ところが 両者の頻度分布図を細かく分析してみると，新潟県全域 では谷密度区分 11 15 領域における地すべり地区数は $8.3 \%$ と非常に少ない。これに対し，東山背斜周辺では 同じ谷密度区分に括ける地すべり地区数が $20 \%$ \%゙り，
全体的に谷密度の低い方へかたよった傾向がらかがわ れるがこの点を特に注目しなければならない（図-4)。 このことは要するに片面箱型褶曲といら地質構造的背 景があることを見拔かねばならないし，この地区の地 すべり分布と発生機構への回想があってしかるべきも のと思われる。この問題については後に述べることに する。

\section{3）地すべりと地層との関係}

東山背斜地区に分布する地層は既に説明したように， 新第三紀層である寺泊層, 椎谷層, 西山層, 烣爪層 （下位より上位へ）と第四紀層の魚沼層などから構成 される。図-5はこれらの各地層が地表に露出する面積, それに対応する地すべり占有面積, および地すべり発 生件数を示したものである。

東山背斜地区に分布する地層の総面積に対するそれ ぞれの地層の占める割合をみると, 魚沼層 $24.4 \%$, 椎 谷層 $23.2 \%$, 灰爪層 $21.1 \%$, 西山層 $19.8 \%$, 寺泊層 8.9\%となっている。このように，背斜軸部にわずか に露出する寺泊層を除けば，魚沼層から椎谷㬝までは ほぼ同じ規模の露出面積を有している。そこでこの面 積に対する地すべり占有面積をみると椎谷層において 最大の地すべり面積を示し, 以下西山層・灰爪層・寺 泊層の順に減少する。な怙東山背斜からは離れるが魚 沼層の地すべりは椎谷層に匹敵する占有面積を示すこ とになる。

一方, 各地層の地表面積に対する地すべり占有面積の 割合をみると, 椎谷層では $19.4 \%$ と最も比率が高く，以 下西山層 $13.8 \%$, 寺泊層 $10.2 \%$, 灰爪層 $7.0 \%$ の順にな る。因みに魚沼層では $7.3 \%$ の高い比率を示している。

つぎに，各地層ごとの地すべり箅所数，地すべりの平 均面積招よび最大面積を比較検討することにする。地す ベり発生箇所数では椎谷層での発生率がきわめて高く50 件にも拉よんでいる。つぎに西山層で26件，灰爪層で19 件，寺泊層で12件の発生件数になっている。またそれぞ 


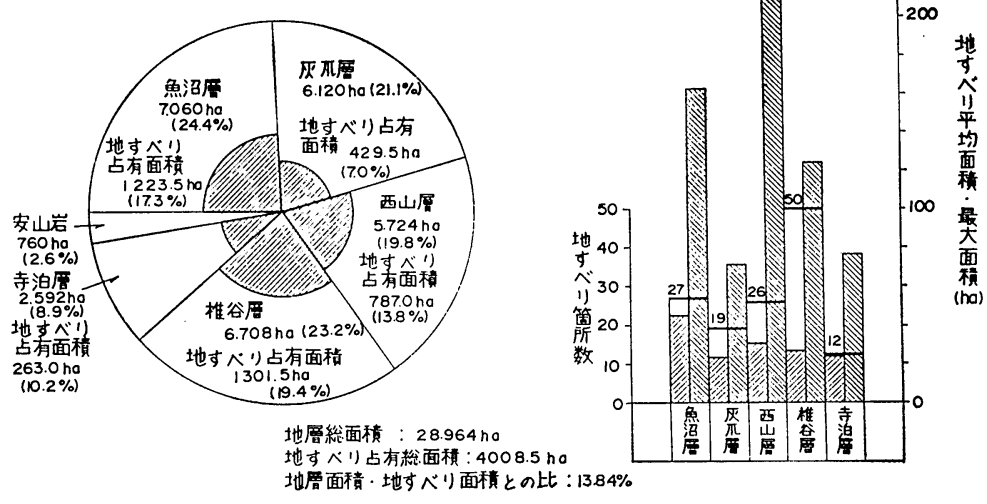

図-5 地層別面積および地すべり面積比発生件数
さて,ここであらためて地質構 造との関係を解析することにした い。しばしば述べたように，東山 背斜は西急東緩の非対称的背斜を 形成している。そして東翼は綵く 東へ傾斜するとともに 2 つ断裂 線を経て上位の地層つまり西山層, 灰爪層になるにしたがって次第に 小盈状構造に分化している。例兄 ば種艼原地すべり地付近がこの構 造に相当している。ところで図-6 にもらかがわれるよらに東翼部に おける地すべり箅所数招よび地す ベり平均面積の增減のパターンは, 上に述べたような地質構造の变化 （分化）を反映している。すなわ ち，巨視的には種艼原に代表され るようにこのタイプの地すべりは
れの平均面積をみると, 西山層で $15 \mathrm{ha}$, 他の地層では 10 ～12 ha になる。な敃魚沼層では 27 件の発生箅所数があ り, 地すべりの平均面積は 20 ha 以上でほかの地層と比 較すると王倒的に大きいことになる。ところで，新潟県 全域に拈ける新第三紀の各地層にみられる地すべり地区 占有獄は山野井徽ほか（1974）に上る研究結果があるが, それによると寺泊・椎谷層が $34.7 \%$ で最も大きい点が指 摘されている。これに比べると東山背斜地区の場合は, 寺泊・椎谷層では16.8\%である。これは東山背斜の北部 では地質の項で述べたように火山岩の熔岩・貫入岩およ び火山砕屑岩を多く介在するために，それらの岩質から 地すべりの発生が比較的少ないものと思われる。しかし ながら，これらの火山岩類を除くと黒色頁岩 の分布するところに限ってい亲ば，地すべり 占有率はかなり高いとい觉るであろう。

\section{4）地盺構造と地すべりとの関係}

東山背斜地区に扔ける地すべり発生と地質 構造との関係は, 本論の焦点でもあるのでこ こで詳論することにする。図-6は東山背斜の 軸部を中心に東翼と西翼に和ける地すべりの 箇所数と面積の割合を示したものである。こ の図をみると両翼ともに軸部から $0.5 \sim 1.0$ $\mathrm{km}$ の距離の範囲内に地すべりが多発してい ることがわかる。また, 東翼と西翼とを比較 してみると、東翼では地すべり箇所数は軸か ら東方へ $0.4 \mathrm{~km}$ 位のところまでの範囲で地 すべり発生頻度が比較的高くなっている。こ のことは山古志村の半蔵金から種艼原さらに 南平に至る地区にかけて地すべりが多く分布 しているということを示している。

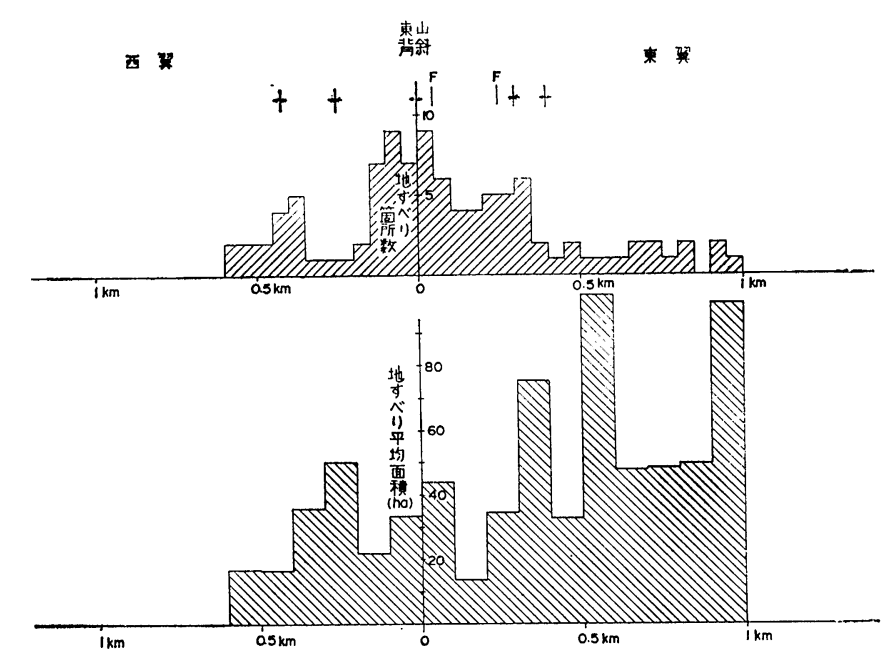

図-6 地質構造と地すべり箇所数・面積との関係

*杉山隆二教授もこの点を指摘されておられる（日本地覚学会第86年学 術大会, 1979年) むしろ向斜構造の部分に位置している点を注目しなけれ ばならない*。言葉をかえていえば，種艼原の場合，(1) 地質構造が盆状構造を形成している。(2)岩質（西山・灰 爪層の砂・碟相）と地下水との関係。この 2 つの地質条 件が地すべりの発生に大きな役割をになっているものと 考察される。そこで種苧原地すべりについて詳説するこ とにする。

種艼原地すべりは, 信越線長岡駅から南東方直距離12 $\mathrm{km}$ ，山古志村の種苧原地内に位置している。この地すへ り地の地質環境は, 西側は東山背斜の中核をなす寺泊・ 椎谷層の熔岩・凝灰角碟岩などから構成される猿倉岳を 中心とする急峻な稜線と, 東側は西山, 灰爪層の泥岩, 


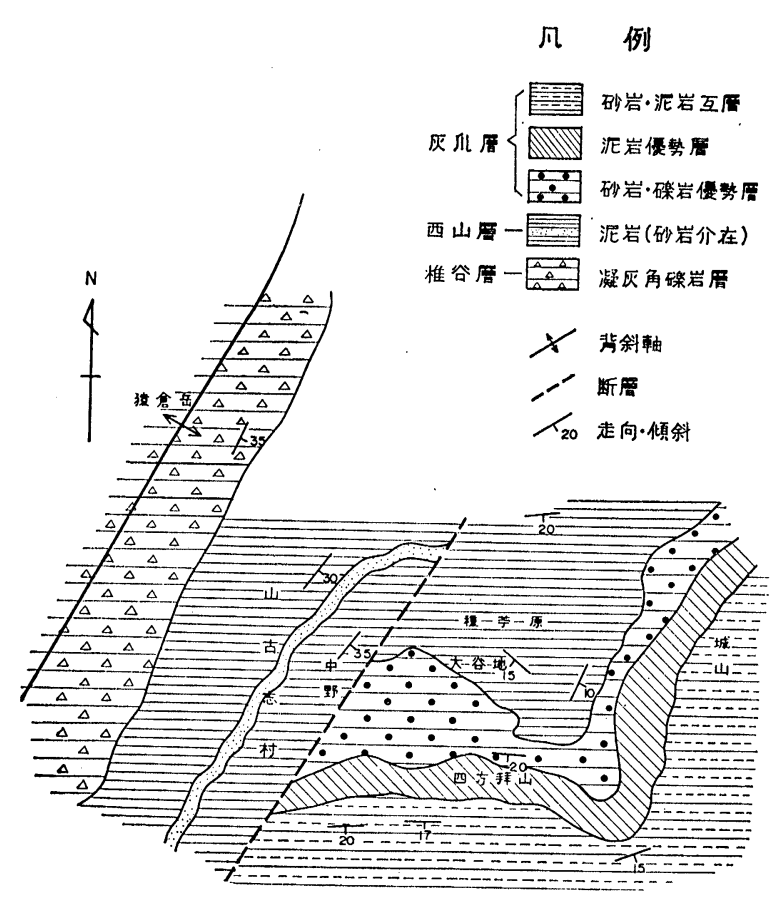

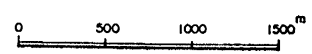

図-7 種艼原付近地質 - 構造図

砂岩，シルト岩などからなる全体的に低い丘陵性の山稜 とに囲まれたところである。すなわち，東山背斜をつく る稜線とは対照的に起伏量の小さい緩傾斜の地形を呈し 半藏金一種艼原一南平に至る特異な盆地を形成してい る。このような盆地状地形の成因は，この地域に分布す る地層の分布と地質構造とに密接な関係を有するものと 考えられる（図-7）。つまり，この盆地は 1 つは灰爪層 基底の䃯岩, 砂岩が優勢な地層から構成されているが, 固結度が低いのが特徴である点があげられる。また他の 1 つは東山背斜の東翼の椎谷層が東へ緩く傾斜している 種艼原部落の西縁に特いて，背斜軸に縦走する NNE 方 向の断層によって切られ，この断層を境にして東側は地 質構造が質的に相違している。すなわち，断層の東側で は走向が $\mathrm{E}-\mathrm{W}$ 方向へ近くなり, 盆状構造へ転化，急変 するという点を注目しなければならない。抏そらく前述 の断裂線は東山背斜の翼部が盆状構造へ分化・発展する 過程で形成されたものであろら。

以上 $2 つ の$ 点について説明したが，この盆状構造と灰 爪層の岩相とは, 東山背斜の山地から供給される地下水 を貯蔵し，停滞するのに格好な地質環境を形成している ものと考察する。特にルーズな十分に固結していない砂 ・磷岩層の地下水貯留層としての役割は大きいといえる。 因みに，この盆地に拈いて西山層の泥岩からの揚水量が $1 \sim 3 l / \mathrm{min} / 3 \mathrm{~m}$ であるのに対し, 盆地の中心部に分布
する灰爪增の砂・磁岩層に停滞する地下水は 12 20 $l / \mathrm{min} / 3 \mathrm{~m}$ といらように極めて大きい揚水量を示し ている。この現象は盆地の地下水はこの付近の地質 構造と岩相とを反映していることを物語っている。

\section{3. 地すべりの発生機構}

これまでにもしばしば述べてきたように，東山背 斜地区に分布する地すべりは基本的には, 東山背斜 の性格に起因するものと考えられる。この背斜の特 徵は北部では非対称的背斜であり, 南部では対称的 背斜という 2 つ構造要素が同一系列の背斜のなか に共存しているという点である。そしてこのような 条件一構造一は, 岩質括よび地形という「質」と 「場」の因子とが相まって地すべり発生の原因をつ くるものと思われる。すなわち，具体的にいうなら ば背斜の西翼部は地層が火山岩・火山砕居岩から構 成されている部分が多く，その結果，椎谷層を例に とっても層厚全体が非常に厚い。したがって, 地表 面の侵食・削例に対する抵抗力が大きいことと地層 の逆転がみられるように急傾斜であるという内的原 因をも加わって，地形面が東翼に比べると急峻であ るといらことが地すべりの発生が少ない原因の1つ であるといえる。つまり雨水，融雪水などの侵透は 急斜面に捈いては少なく，その結果，地下に侵入す る前に地表面を流出してしまうことになろう。したがっ て，地下に护浸透水による泥質岩の粘土化（風化） といったような現象もおそらく活発には行なわれないも のと推察する。誩そらく西翼部に発生した断裂の発達状 態などからみると岩体自体のなかの地下水がそこに停滞 する時間はそれほど長くはないであろら。

これに対して，東翼部では地層の傾斜も緩く西翼部に 比べると厚さが非常に薄い。これは果翼部では椎谷層の 火山确屑岩の介在が量的に少なく，これに代えて凝灰質 砂岩が発達することによるものである。また，椎谷層に 限らずそれより上位の西山・灰爪層や魚沼層の各層につ いても層厚についていえば同じような傾向がみとめられ る。このような現象は褟曲を形成する運動の性格が背景 にあるわけで, 東山背斜の東翼部にみられる盆状構造へ の分化もまたこのような造構運動の反映としてとらえる べきである。したがって東翼部にも小さい単位でのテク トトープがあるといらことになり，その結果，そこには 地形的条件とともに背後地からの浸透水の集積もこのよ らなテクトトープに規制されるものといら考察が必要で ある。つまり，もっと具象的にいうならば，地質構造と しては小盈状構造ないし半盆状構造といら形態的集水条 件と貯留層としての岩相的集水条件とが東翼にはよく整 っているということができる。な批，これに東山背斜東 翼の断裂系の存在は永みちとして当然考慮されなければ 
ならないことは言をまつまでもなかろら。すなわち，前 項に扰いて説明したよらに，東山背斜地区の地すべり简 所数, 面積と地質構造との関係を示すへキサダイヤクラ ム（図-6）にもらかがわれるよらに，背斜の北部に扣い ては西翼に比べると東翼では地すべり面積も大きく，か つ背斜軸からかなり離れたところにも分布が広いのが特 徵であるとともに，地質構造的位置からするとむしろ向 斜部にあたっていることになる。このタイプの地すべり の好例は種艼原地すべりである。既に述べたようにこの 地すべりの発生機構は, 小盆状構造と岩質的に灰爪層基 底の岩相が透水性が大きいことに原因がある。特に種䒓 原地すべり地の平坦なところでは地盤沈下現象がみられ， かつパイピングのよらな挙動さえ観察されるのはこれを 暗示するものであろう。すなわち，このタイプの地すべ りの原因としては構造的要素と岩質的要素とが共存して いるもので，構造性地すべりと岩質性地すべりとの両者 が複合しているものと考える。蛇足的説明を許容される ならば，いまここに「場」の条件である構造的条件を考 えてみることにする。東山背斜はその性格からして，西 翼部は側方圧縮性応力場にあるとい方る。つまり，この 褶曲は東から西へ働く横断方向に最大圧縮主応力軸をる つ応力場で形成された構造であると推考できる。これを 裏書きするのは岩石物性の差異にも表現されている。例 えば両翼における椎谷層の砂岩を比較してみると, 同じ 岩質の同じ凮準に括ける凝灰質砂岩の压縮強さは，西翼 部のそれに比べると東翼部の砂岩は $1 / 3 \sim 1 / 10$ といら強 度の岩石試験結果のデータがえられている*。すなわち, ここで強調したいのは造構造環境と岩石物性との間には かなりの相関性があるといらことである。なお東山背斜 北部之荷頃背斜との中間にあたる向斜部にも“栃䆶地す ベり”などがみられるがこれらもまたこのタイプに属す るあのであろう。

ところが一方，これらに対して東山背斜南部や荷頃背 斜に分布する地すべりは，これまで述べたるのに比べる と位置的には軸部に集中して発生している点を指摘でき る。例えば虫亀, 下平, 矢津などの地すべりがその例で ある。このタイプの地すべりは中央油帯背斜軸部に分布 する地すべりで, 筆者の 1 人西田が提案したように原因 からいらと構造性地すべりの典型的なものである。すな わち, このタイプの地すべりは, 褶曲の成因としては座 屈による要素が強く, 褶曲形成の過程で主に水平王縮応 力による slip と flow をともなら後生的岩石物性の变化 （破壊）が素因となったものと考察する。既に述べたよ らに東山背斜の構造的要素にもこれをらかがうことがで きる。

ところで, 東山背斜の南端は上越線川口駅の南西方向 にあたる高場山付近で沈入背斜 plunging fold となり軸 が傾いている。すなわち軸の沈入部では軸方向に引張り による開口性の断裂が形成されるはずである。事実, 19 71年 1 月に高場山トンネル地すべりはこのような位置に 発生した。この場合, 滑落崖で観察された西山層の泥岩 は著しく破碎されている。したがって高場山トンネル地

*この問題については近く報告する予定である。
すべりも背斜の特殊な場所に発生した構造性地すべりの 範疇に含められるべきものと考秃る。

以上に述べたよらに，東山背斜地区の地すべりは，こ の背斜の性格（非対称性, 対称性, 軸つ分岐などの特 性）からして，構造性地すべりと岩質性地すべりとが共 存しているといらことになろら。さて，地すべり現象の 原因を植村 武 (1975) は, 内的原因と外的条件の 2 つに 分けているが，同氏によれば外的条件は「場」の因子か ら構成されている。すなわち，地形もまた「場」の因子 に依存するもので, 地形の基本は造構造力による隆起・ 沈降と風雨などの営力による地表面の侵食・削刯によっ て決まるといえる。したがってこれらの因子は一定不変 のものではなく時とともに変化する。褶曲構造のなかに は活褶曲之呼ばれる現象があるが，このタイプの褶曲は 現在もな扰造構造力の余命が継続しているものである。 つまり，水準点が褔曲の背斜のところで上昇し，向斜の ところでは沈下するといら性格の褶曲である。ところで 東山背斜は果たしてどらであろらか。

これまでの水準点測量の結果では, 新潟県下でいくつ かの褶曲が現在もな就活動していることが知られている。 また，水準点と地質構造との対応関係があることも指摘 されている。例えば東山背斜の南部を横切る小出一小千 谷ルート, 中央油帯背斜の南部を横切る柏崎一長岡ルー トはその代表的なものである。いずれも褶曲の背斜の部 分が現在も隆起し, 向斜の部分が沈降している。向斜部 の水準点を基準にして背斜軸付近に設畕された水準点の 相対的な成長速度を求めると，小出一小千谷ルートで $0.54 \mathrm{~mm} / \mathrm{Yr}$, 柏崎一長岡ルートでは $2.8 \mathrm{~mm} / \mathrm{Yr}$ とな っている。ここでも注目されるようにほかの背斜に比へ て中央油带背斜の背斜部の平均速度が桁違いK大きい点 である。この背斜軸に沿って直線状に活動中の地すべり や過去に活動した地すべりが集中して発生しているとい ら事実は注目すべきである。また，中央油帯背斜軸部の 地すべり地に観察される地質構造は薬師峠トンネル地す ベりの例にみられるよらに，そこには背斜部に縦走する 高角・開口性の正断層のほかに座屈褶曲の進行にともな ってできる低角の衝上断層が形成されているといら寒例 をあげることができる。その結果, 岩石自体がかなり破 碎されている。背斜軸部に多発するこのタイプの地すべ りはこの背斜頂部の断裂そのものが地すべり素因となる ものと考光る。したがって東山背斜南部の地すべり群に も素因（内的原因）としては構造的因子を考虑すべきで ある。そしてさらに推考すべきは，これらの因子ととも にその背景には地形といら因子（外的条件）とともに造 構造応力史への回想が必要であろら。そこで, ここにあ らためて提起しなければならぬことは地すべりの発生機 構と活褶曲といら問題である。

活褶曲と地すべりとの関係については, 高野武男 (19 60), 岩松 輝（1975）らによって両者の間には関係が あることが提言されている。高野は秋田県, 山形県下に おいて褶曲帯の背斜部に地すべりが多いといら点に注目 し，この分布傾问は活褶曲と何らかの関係にあるもので あろらと述べている。この発想はやはり同氏の長い経験 
の蓄積から生まれた卓見であろら。しかし，同氏も述べ ているよらに両者の関係については今日な和明確にこれ を説明でさる段階にないとい光るよらである。しかし， 近年, 地質学に批ける 1 つの分野である構造物理学 $\mathrm{Te}$ ctonophisics のめまぐるしい進歩により野外に括ける岩 石（地層の変形・破壊に関するメカニズムが理論的に説 明されるよらになった。したがって，地すべりと活䙮曲 といった問題でも造構造応力史といら観点から解明され てきている。すなわち，背斜軸に沿って直線状に分布す るといら地すべり現象についても造構造運動を考虑に入 れた力学的アプローチが必要であり，今日こらいった視 点からの研究がようやく進められつつある状態になって きたとい方る。一方，玉田喜三郎（1973，1980）はこの よらな考察とは別に, 工学的立場から新規地すべり発生 特に打ける破壊条件について報告し，潜在すべり面とい ら概念を提言している。同氏は潜在すべり面について “過去の地質構造運動によって, 地層中に生成したwater film 面（一種のせん断破壞面）といら超薄層, 超弱面の 亀裂が多数入っている集合帯のことで, 地層中の一種の 弱面に相当する。といらように説明している。として この生成機構については地質学的背景があるといらよう К大変興味ある言葉で緅っているが，この意味には $1 つ$ は地形面の隆起量を考虑しているようにらかがうことが できる。つまり,活褶曲帯にみられる水準点の相対的な成 長速度 $0.54 \mathrm{~mm} / \mathrm{Yr}$ (東山背斜南部), $2.8 \mathrm{~mm} / \mathrm{Yr}$ (中央 油帯背斜）といら数值からすると玉田氏の潜在すべり面 は生成されることになる*。筆者らはこの場合, 同氏の 潜在すべり面そのものの存在を肯定しているわけではな いが，それにしても一脈通ずるともい方る別個な思考を もっている。というのはフレキシュラル・スリップ褶曲 作用 flexural-slip folding により層状岩石にでさるたわ み（主として層理またはそれに平行な面構造にできる平 行なすべり）という構造物理学的な物性に基づく内的原 因と地形的因子とが相重なって岩体のなかに一種のせん 断破壊面ができ，これが地すべり面の形成に連なるので はなかららかと推察するものである。すなわち, 活褶曲 といら造構造運動も地すべり発生に深い関係があること をあらためて強調するとともに，この意味から東山背斜 南部の地すべり群についても上に述べたような側面観が 必要であろら。

\section{むすび}

東山背斜地区に発生した地すべり地は，分布の傾向か らすると著しい特徵がみとめられる。これはまず第一に 指摘できる点は, 基本的には地質構造を反映していると いらことである。すなわち, 東山背斜北部の構造は非対 称的背斜であり, 西翼の傾斜は急, 一部逆転, これに対 して東翼は緩いといら大きな相違がみられる。これはお そらく褶曲の成因，性格を暗示するすのであらう。一方， これに対し背斜南部は対称的背斜を形成している。地す ベり地は背斜の北部に限っていらならば東翼では軸部か

*年間《隆起量が $0.1 \mathrm{~mm}$ 以上あれば潜在すべり面ができるといらこと である (玉田教授の御教示による)。
らやや離れたところか, むしろ向斜部に近い場所に位置 している。これに対して背斜南部ではこの傾向とは異な り背斜軸部に集中している。このように同一系列の背斜 に扔いてもこのように地すべり発生の場所が位置的に大 きく相違しているのは要するにテクトトープに規制され たものと考察する。このように東山背斜南部の地すべク は原因・発生機構ともに中央油帯背斜の地すべりに類似 して括り，したがって構造性地すべりの類型に含まれる。 これに対し，背斜北部の地すべりはもともと岩質が主因 であり，これに加えて造構造運動にともなら応力場の条 件を反映するもので岩質性地すべりの範睰に入るもので ある。ところで, 東山背斜地区ではな捻かつ注目すべき 現象は東翼に続く向斜部に盆状構造に規制された特異な タイプの地すべりが大規模に発生しているといら点であ る。以上に述べたよらに, 東山背斜地区の地すべりは, 発生原因（素因）から推考すると構造性地すべり・岩質 性地すべり・岩質一構造性地すべりが複合している発生 機構のらえでは複雑な地すべり地帯であるということが できる。

\section{参考文献}

高野武男（1960）：地すべりと防止工法, 地球出版, p. 121-123 山田㓮二・小橋澄治・草野国重 (1971)：高場山トンネルの地す ベりによる崩壊, 地すべり, Vol.7, No.5

曷田忠夫 三梨 昂- 影山邦夫- 宮下美智夫- 鈴木尉元 (1974) : 東山背斜の層序々地質構造, 地質調查所報告, 第 250 号 -1

小玉喜三郎·樋口茂生 (1974) : 東山背斜翼部の断層系, 地質調 査所報告, 第2 250 号-2

鈴木棋元 - 三梨 昂・影山邦夫 - 島田忠夫 - 宮下美智夫 - 小玉喜 三郎 (1974) : 新潟第三系堆積盆地飞発達する袺曲の形成機構 について, 地質調查所報告, 第 250 号 -2

小玉喜三郎・鈴木尉元・小川銀三・丸田美幸 (1974) : 箱型褶曲 の内部構造についてースケール・モデル実験による研究, 地質 調査所報告, 第 250 号 -2

小玉喜三郎・鈴木尉元・宮下美智夫・相馬庸三 (1974) : 上·中 越地域の水準点変動々地質構造の相関, 地質調査所報告, 第250 号-2

永田 聡・神田 章·馬場一雄・須田光治 (1974) : 新潟県の地 すべり分布と地形について，地すべり，Vol. 11， No. 3

山野井徹・石黒重実・布施 弘・神田章 (1974) : 新潟県の 地すべりとその環境，地すべり，Vol. 11，No.2

岩松 輝・服部昌樹・西田彰一 (1974) : 地すべりと岩石の力学 的性質, 地すべり, Vol.11, No.1

西田彰一（1975）: 第三紀層の地すべり発生と予測の研究, 文部 省科学研究費自然災害特別研究研究成果, No. A-50-6

岩松 輝 (1975) : 新潟県下の地すべりとしゅら曲作用, 新潟大, 理学部地盤災害研究施設, 研究年報, 第 1 号

植村 武 (1975)：地すべりの分類と予測, 文部省科学研究費自 然災害特別研究研究成果, No. A-50-6

西田彰一・岩松 輝（1976）：北部フォッサマグナ地域の地すべ り，昭和50年度自然災害特別研究「フオッサマグナ北部地域に 扣ける崩災の発生機構と予測敒関する研究」成果報告

垣見俊弘 (1978): 地質構造の解析, 地学双書22. 地学団体研究会 Makiyama, J (1978) : Tectonomechanics, Tokai University Press

玉田文吾（1980）：新規地すべり発生時におけりる地すべり面の形 状, 地すべり, Vol.16, No. 4

（原稿受理日 昭和55年 6 月10） 


\section{長野県下伊那郡大鹿村小塩沢地すべりについて \\ 「地すへり」Vol. 17, No. 4 (通巻第64号) 1981年（昭和56年）3月 \\ 北沢 秋司}

これまでの調査によって，この地すべりの特徵及び対策を，次のようにまとめることができる。

（1）三波川帯結晶片岩類の破砕が著しい地帯に発生していて，地すべり形態が不完全で，地すへりり性崩壊に類 別される。

（2）断層によって分断されたブロック内に発生しているもので，ここはまた古い地すべり地形である。

（3）基盤に漫透した地下水によって，破砕部が膨潤化して，それが表面に突出して，滑落崖を形成した。

(4) 滑落崖は, 蛇紋岩の貫入部で, このような弱線部が 2 本ある。

（5）小塩沢に施工した，床固工及び谷止工によって，渓床が上昇し，地すべり地内に地下水を漫透させた。

（6）対策としては，主として地すべり地頭部の地下水の排除に重点を置くことが望ましい。

新潟県東山背斜の地すべりとテクトトープ

「地すべり」Vol. 17, No.4（通巻第64号）1981年（昭和56年）3月

寺川 俊浩, 和久 紀生, 西田 彰一

小論は，新潟県東山油田に発達する東山背斜帯に分布する地すべり発生の素因と機構に関する構造地質学的考 察を行なったものである。東山韭斜は北の部分では非対称的背斜を形成し, 西翼の傾斜は急, 東翼は緩く, 地す ベりは東翼部に多発している。この傾向は岩質（物理的・化学的性質）が内的原因となるものである。これに対 し，背斜南部では対称的急傾斜の背斜となり，地すべりは背斜軸部（頂部）に集中して発生する。これは持そら く軸部の断裂による破砕が起因となるものであろう。つまり，背斜北部は岩質性地すべり，南部は構造性地すべ りに区分できるように，この地带の地すべりは同一系列の背斜にありながら，その類型は個々の構造単元の性格 に規制されている。

Time Dependent Behavior of Soil during Direct Shear Creep

「地すへり」Vol. 17，No.4（通巻第64号）1981年（昭和56年）3月

\section{Fujiya Комамura}

An equation for creep curve which can be used to characterize the creep behavior of soils is derived from creep test results. The equation which consists of the terms expressing the primary creep, secondary creep and tertiary creep is valid to describe the creep behavior over any time period.

The time to creep failure under a sustained stress decrease with increase in water content and stress level. The prediction of time to failure in soil creep was discussed by applying the displacement-time equation and the theory of rate process. The equation for prediction of creep failure of soil is derived as a negative exponential function of stress and water content.

新潟県の地すべりと地質および地質構造の関係 (2)

「地すべり」Vol. 17，No.4（通巻第64号）1981年（昭和56年）3月

福本 安正

崖崩れによる家屋被害に関する調查研究

「地すへり」Vol. 17, No. 4 (通巻第64巻) 1981年（昭和56年）3月

鵜飼 恵三, 石橋 正司, 竹洞 一則

昭和53年 6 月の新潟水害時に発生した崖崩れによる家屋被害に関し，その原因の究明及び防止対策の立案の一 助となることを目的として, 調查研究を行なった。調查は独自に作成した調査表にもとづき, 一つ一つの崖崩れ について聞き込み及び現場調査を行なった。この結果, 崖崩れの多くには崩壞前に前兆現象が見られたこと, 家 屋の大部分は敷地内で切土の崖に接近して建てられていること, 過去に崩壊の経歷がある崖では少ない降雨量で 崖崩れが発生していることなどが明らかになった。 